PNNL-11054

UC-512

Project Technical Information

RECEIVED

APR 041996

OSTI

Report for Westinghouse Hanford

Company: Makeup Procedures and

Characterization Data for Modified

DSSF and Modified Remaining

Inventory Simulated Tank Wastes

R. O. Lokken

March 1996

Prepared for the U.S. Department of Energy

under Contract DE-AC06-76RLO 1830

Pacific Northwest National Laboratory

Operated for the U.S. Department of Energy

by Battelle Memorial Institute 
PNNL-11054

UC-512

Project Technical Information

\section{Report for Westinghouse Hanford Company: Makeup Procedures and Characterization Data for Modified DSSF and Modified Remaining Inventory Simulated Tank Wastes}

R. O. Lokken

March 1996

Prepared for

the U.S. Department of Energy

under Contract DE-AC06-76RLO 1830

Pacific Northwest National Laboratory

Richland, Washington 99352

Reprint of historical document PVTD-C95-02.03D, dated May 1995. Data, formatting, and other conventions reflect standards at the original date of printing. Technical peer reviews and editorial reviews may not have been performed. 


\title{
DISCLAIMER
}

This report was prepared as an account of work sponsored by an agency of the United States Government. Neither the United States Government nor any agency thereof, nor Battelle Memorial Institute, nor any of their employees, makes any warranty, express or implied, or assumes any legal liability or responsibility for the accuracy, completeness, or.usefulness of any information, apparatus, product, or process disclosed, or represents that its use would not infringe privately owned rights. Reference herein to any specific commercial product, process, or service by trade name, trademark, manufacturer, or othenwise does not necessarily constitute or imply its endorsement, recommendation, or favoring by the United States Government or any agency thereof, or Battelle Memorial institute. The views and opinions of authors expressed herein do not necessarily state or reflect those of the United States Government or any agency thereof.

\author{
PACIFIC NORTHWEST NATIONAL LABORATORY \\ operated by \\ BATTELLE \\ for the \\ UNITED STATES DEPARTMENT OF ENERCY \\ under Contract DE-AC06-76RLO 1830
}

\author{
Printed in the United States of America \\ Available to DOE and DOE contractors from the \\ Office or scientiulc anó Tecinnical infurnation, F.O. Bux 62, Oả' Ridge, TN 37831; \\ prices available from (615) 576-8401.
}

\begin{abstract}
Available to the public from the National Technical Information Service, U.S. Department of Commerce, 5285 Port Royal Rd., Springfieid, VA 22161
\end{abstract}




\section{SUMMARY}

The majority of defense wastes generated from reprocessing spent reactor fuel at Hanford are stored in underground Double-Shell Tanks (DST) and in older Single-Shell Tanks (SST). The Tank Waste Remediation System (TWRS) Program has the responsibility of safely managing and immobilizing these tank wastes for disposal. A reference process flowsheet is being developed that includes waste retrieval, pretreatment, and vitrification. Melter technologies for vitrifying low-level tank wastes are being evaluated by Westinghouse Hanford Company. Chemical simulants are being used in the technorogy testing.

For the first phase of low-level waste (LLW) vitrification simulant development, two waste stream compositions were investigated. The first waste simulant. was based on the analyses of six tanks of double-shell slurry feed (OSSF) waste and on the projected composition of the wastes exiting the pretreatment operations. A simulant normalized to $6 \mathrm{M}$ sodium was based on the anticipated chemical concentrations after ion exchange and initial separations. The same simulant concentrated to $10 \mathrm{M}$ sodium would represent a waste that had been concentrated by evaporation to reduce the overall volume. The second LLW simulant, referred to as the remaining inventory (RI), included wastes not included in the DSSF tanks and the projected LLW fraction of single-shell tank wastes.

Several compositions of LLW simulants were developed for use in the Phase 2 melter vendor tests. The simulants included DSSF. modified DSSF. RI and modified RI. The DSSF was the same composition that was developed and tested for the Phase 1 tests. One of the objectives of the Phase 2 melter vendor tests is to investigate the impacts of waste composition variability.

The waste composition variability issue was addressed by looking at tank inventory data files. Based on these data, it was found that, in general, most of the $C 1$ and $F$ is concentrated in DST sources and the majority of $P$ and $S$ is concentrated in SST sources. The current DSSF simulant is intended to be a surrogate for the DST wastes and the current RI is intended to be a surrogate for the much larger volume SST wastes. The modified DSSF simulant 
was spiked with $\mathrm{Cl}$ and $\mathrm{F}$ at or near levels which would result in concentrations at their solubility limit in normal silicate waste giasses. Based on a 25 wt\% waste oxide loading in the glass, the simulants were spiked at two, three, and four times their glass solubility limits. Similarly, the modified RI contained two, three, and four times the solubility of $\mathrm{P}_{2} \mathrm{O}_{5}$ and $\mathrm{SO}_{3}$.

Two mixtures of various trace metals were prepared for possible inclusion in the Phase 2 melter testing. Certain metals that have been identified in small quantities in the LLW composition data base have the potential for causing processing problems. The metals were selected from inventories of metals greater than 0.5 metric tons. The first mixture contained $B i, C d, N i$, $\mathrm{Pb}, \mathrm{Zn}, \mathrm{Sb}$, and $\mathrm{Mo}$; the second mixture contained $\mathrm{Cu}, \mathrm{Zn}, \mathrm{Pb}, \mathrm{Mn}, \mathrm{Ni}, \mathrm{Sn}, \mathrm{Sb}$, Mo, As, and $\mathrm{Cr}$.

Laboratory prepared simulants were characterized for settled solids. density, viscosity, moisture content, and chemical analyses. Following laboratory development and characterization of the simulants, a procedure was recommended for use in preparing large quantities of LLW simulant for use in the Phase 2 melter vendor tests. Procedures were also developed for preparing the two metals mixtures. 


\section{CONTENTS}

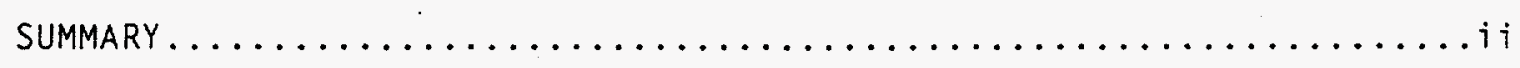

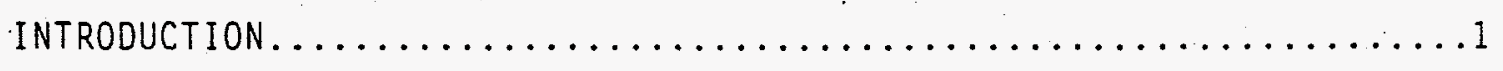

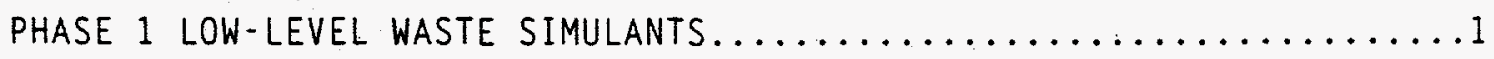

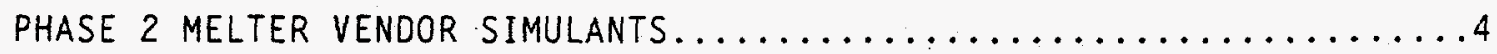

REDUCIBLE METALS AN SEMI-VOLATILES SIMULANT ADDITIVES .........11

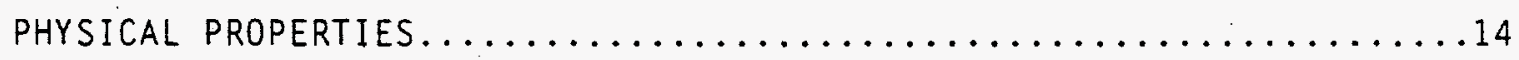

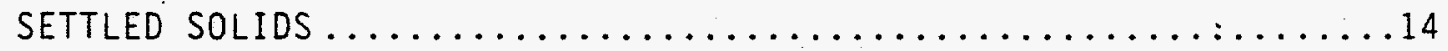

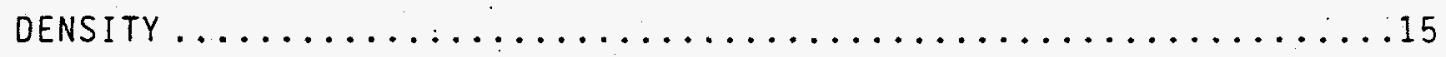

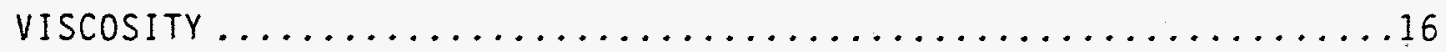

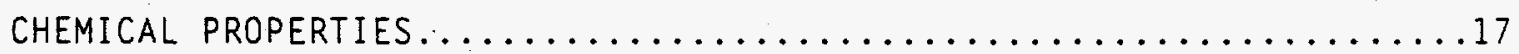

RECOMMENDED PROCEDURE FOR PHASE 2 SIMULANT PREPARATION........... 25

RECOMMENDED PROCEDURE FOR PHASE 2 METALS MIXTURE PREPARATION .......26

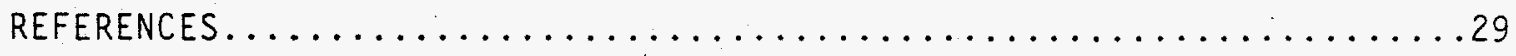




\section{TABLES}

I Concentrations of Low-Level Tank Waste Simulants Tested During

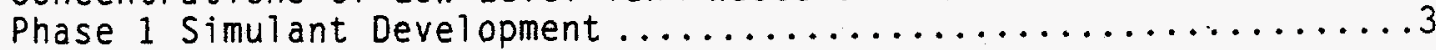

2 Oxide Composition of the Original and Modified DSSF Simulants ....5

3 Oxide Composition of the Original and Modified Remaining

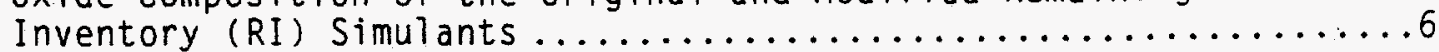

4 Ionic Concentration of Phase 2 DSSF Simulants .............

5 Ionic Concentration of Phase 2 Remaining Inventory (RI)

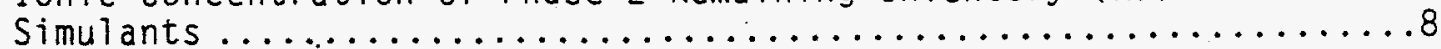

6 Batch Sheet for Phase 2 DSSF Simulants $\ldots \ldots \ldots \ldots \ldots \ldots \ldots$

7 Batch Sheet for Phase 2 RI Simulants ...................

8 Batch Sheet for Metals Mixture No. $1 \ldots \ldots \ldots \ldots \ldots \ldots \ldots$

9 Batch Sheet for Metals Mixture No. $2 \ldots \ldots \ldots \ldots \ldots \ldots \ldots \ldots$

10 Estimated Volume Percent Settled Solids...................

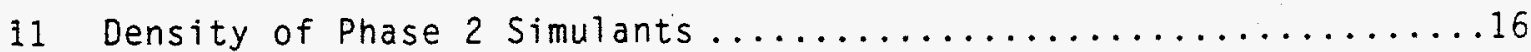

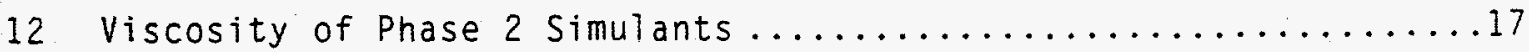

13 Moisture Content of Phase 2 Simulants ................... 18

14 Nominal and Analyzed Composition of DSSF and M-DSSF ..........19

15 Nominal and Analyzed Composition of RI and M-RI ..............

16 Analyzed Chemical Composition of M-DSSF at Various Stages of

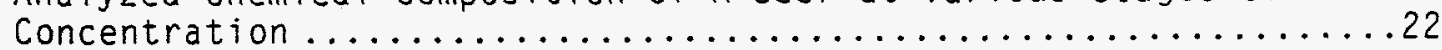

17 Analyzed Chemical Composition of M-RI at Various Stages of

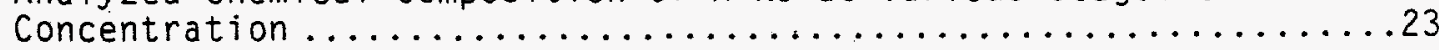

18 Nominal and Analyzed Composition of Metals Mixture 1

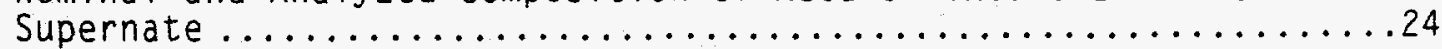

19 Nominat and Analyzed Composition of Metals Mixture 2

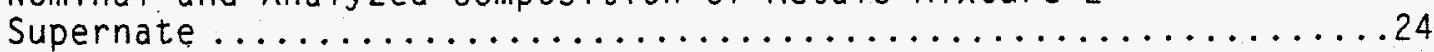




\section{ACRONYMS}

$\begin{array}{ll}\text { DSSF } & \text { Double-Shell Slurry Feed: } \\ \text { DST } & \text { Double-Shell Tank } \\ \text { ICP } & \text { Inductively Coupled Plasma spectroscopy } \\ \text { LLW } & \text { Low-Level Waste } \\ \text { PNL } & \text { Pacific Northwest Laboratory } \\ \text { RI } & \text { Remaining Inventory } \\ \text { SST } & \text { Single-Sheli Tank } \\ \text { TWRS } & \text { Tank-Waste Remediation System } \\ \text { WHC } & \text { Westinghouse Hanford Company } \\ \text { M-DSSF } & \text { Modified Double-Shell Slurry Feed } \\ \text { M-RI } & \text { Modified Remaining Inventory } \\ \text { TCLP } & \text { Toxicity Characteristic Leaching Procedure }\end{array}$




\section{INTRODUCTION}

The majority of defense wastes generated from reprocessing spent reactor fuel at Hanford are stored in underground Double-Shell Tanks (DST) and in older single-Shell Tanks (SST) in the form of liquids, slurries, sludges, and salt cakes. The Tank Waste Remediation System (TWRS) Program has the responsibility of safely managing and immobilizing these tanks wastes for disposal. A reference process flowsheet is being developed that includes waste retrieval, pretreatment, and vitrification.

PNL is assisting in the development of waste forms for vitrifying Hanford LLW and is supporting the Westinghouse Hanford Company melter technology selection. An integral part of the process is to identify, prepare, and characterize representative LLW simulants for use in these studies. During FY-94. procedures were developed for preparing waste simulants for use in laboratory vitrification studies and for Phase 1 melter vendor tests (Lokken and Martin 1994; Lokken 1995) as described in the PNL Project Work Plan and the WHC Vendor Test Statement of Work (Wilson 1994), respectively. Current activities have focused on developing simulants for use in the phase 2 melter vendor tests. This report describes the basis for the simulants developed for Phase 2 testing, chemical and physical properties of the simulants and the recommended recipe for preparation.

\section{PHASE 1 LOW-LEVEL WASTE SIMULANTS}

For the first phase of LLW vitrification simulant development, two "reference" waste streams were investigated. The first waste stream simulant was based on the analyses of six tanks of Double-Shell slurry Feed (DSSF) waste and on the projected composition of the wastes exiting the pretreatment operations (Shade 1994). A simulant normalized to $6 \mathrm{M}$ sodium was based on the anticipated concentration after ion exchange and initial separations. A $10 \mathrm{M}$ sodium simulant would represent the same waste that has been concentrated by evaporation to reduce the overall volume. The only difference between these two simulants is the water content; the species and their relative amounts are the same. 
The second LLW stream simulant, referred to as the remaining inventory $(R I)$, included wastes not included in the DSSF tanks and the projected LLW fraction of single-shell tank wastes (Shade 1994). Essentially: this waste stream encompasses the entire inventory of tank wastes except for that included in the DSSF waste stream discussed above.

Development and characterization of these simulants are described in Lokken and Martin (1994) and Lokken (1995). Table 1 lists the nominal compositions of the three simulants. The $10 \mathrm{M}$ DSSF simulant was used in the Phase 1 melter vendor tests (Wilson 1994). 
TABLE 1. Concentrations of Low-Level Tank Waste Simulants Tested During Phase 1 Simulant Development, moles/L

\begin{tabular}{|c|c|c|c|}
\hline Component & $\begin{array}{c}\text { DSSF } \\
6 \mathrm{M} \mathrm{Na}\end{array}$ & $\begin{array}{c}\text { DSSF } \\
10 \mathrm{M} \mathrm{Na}\end{array}$ & $\begin{array}{l}\text { Remaining } \\
\text { Inventory }\end{array}$ \\
\hline A1 & 0.61 & 1.02 & 0.16 \\
\hline $\mathrm{Ca}$ & 0.00063 & 0.00105 & 0.0004 \\
\hline $\mathrm{Cr}$ & 0.0052 & 0.00867 & 0.0042 \\
\hline $\mathrm{Fe}$ & 0.00046 & 0.000767 & 0.00024 \\
\hline$K$ & 0.30 & 0.50 & 0.0058 \\
\hline $\mathrm{Mg}$ & 0.00062 & 0.00103 & 0.0000011 \\
\hline$M n$ & 0.00025 & 0.000417 & 0.001 \\
\hline Mo & 0.01 & 0.0167 & 0.01 \\
\hline $\mathrm{Na}$ & 6.0 & 10.0 & 6.0 \\
\hline $\mathrm{Sr}$ & 0.01 & 0.0167 & 0.01 \\
\hline Cs & 0.01 & 0.0167 & 0.01 \\
\hline $\mathrm{PO}_{4}$ & 0.026 & 0.0433 & 0.11 \\
\hline $\mathrm{IO}_{4}$ & 0.01 & 0.0167 & 0.01 \\
\hline $\mathrm{CO}_{3}$ & 0.16 & 0.267 & 0.05 \\
\hline$C 7$ & 0.096 & 0.127 & 0.0092 \\
\hline$F$ & 0.15 & 0.25 & 0.13 \\
\hline $\mathrm{SO}_{4}$ & 0.026 & 0.0433 & 0.038 \\
\hline $\mathrm{NO}_{3}$ & 1.9 & 3.11 & 3.5 \\
\hline $\mathrm{NO}_{2}$ & 1.0 & 1.67 & 0.26 \\
\hline $\mathrm{OH}$ & 2.3 & 3.8 & 1.5 \\
\hline TOC & 0.81 & 1.35 & 0.11 \\
\hline
\end{tabular}




\section{PHASE 2 MELTER VENDOR SIMULANTS}

Eight compositions of LLW simulants were tested for use in the Phase 2 melter vendor tests being conducted for Westinghouse Hanford Company. The simulants included DSSF, three variants of modified DSSF (M-DSSF), RI and three variants of modified RI (M-RI). The DSSF was the same composition that was developed and tested for the Phase 1 tests (Lokken and Martin 1994: Lokken 1995). One of the objectives of the Phase 2 melter vendor tests is to investigate some issues of the vitrification process that were not addressed in the Phase 1 tests. The issues can be grouped into two classes, related to processing issues and to product issues:(a)

Processing Issues:

Recycle of Melter Effluents,

Semi-Volatile Metals,

Solubility of P, S, F, Cl.

Maximum Liquidus Temperature Operating Range, and

Waste Compositional Variability Related to Flowsheet.

Product Issues:

Waste Loading,

G1ass Product Durability.

Waste composition variability was addressed by analyzing tank inventory data files. Based on these data, it was found that, in general, most of the $\mathrm{Cl}$ and $\mathrm{F}$ is concentrated in DST sources and the majority of $\mathrm{P}$ and $\mathrm{S}$ is concentrated in SST sources. The current. DSSF simulant is intended to be a surrogate for the DST wastes and the current RI is intended to be a surrogate for the much larger volume SST wastes. Consequently, it was decided to spike the DSSF simulant with $C l$ and $F$ and to spike the RI with $P$ and $S$ as discussed below.

The modified DSSF simulant was spiked with $C l$ and $F$ at levels which would result in concentrations at or near their solubility limit in normal silicate waste glasses(a). Based on a 25 wt\% waste oxide loading in the glass, the

(a) Shade, J.W. January 5, 1995, Update on Phase 2 Simulants, via cc:Mail. 
simulants were spiked at four, three, and two times their, glass solubility limits. Similarly, the modified RI contained four, three and two times the solubility of $\mathrm{P}_{2} \mathrm{O}_{5}$ and $\mathrm{SO}_{3}$. The "modified" oxide composition of the simulants was normalized to $100 \%$ oxides after the addition of the $\mathrm{Cl}$ and $\mathrm{Fl}$ or $\mathrm{P}_{2} \mathrm{O}_{5}$ and $\mathrm{SO}_{3}$. The nominal oxide compositions of the "modified" LLW simulants are listed and compared with the original compositions in Tables 2 and 3.

IABLE 2. Oxide Composition of the Original and Modified DSSF Simulants

\begin{tabular}{|c|c|c|c|c|}
\hline \multirow[b]{2}{*}{ Oxide } & \\
\hline & DSSF & $M-\operatorname{DSSF}(2 x)$ & $M-\operatorname{DSSF}(3 x)$ & $M-D S S F(4 x)$ \\
\hline $\mathrm{Na}_{2} \mathrm{O}$ & 72.67 & 69.12 & 65.49 & 61.86 \\
\hline $\mathrm{K}_{2} \mathrm{O}$ & 5.77 & 5.49 & 5.20 & 4.91 \\
\hline $\mathrm{Al}_{2} \mathrm{O}_{3}$ & 12.70 & 12.08 & 11.45 & 10.81 \\
\hline $\mathrm{CaO}$ & 0.01 & 0.01 & 0.01 & 0.01 \\
\hline $\mathrm{Cr}_{2} \mathrm{O}_{3}$ & 0.16 & 0.15 & 0.14 & 0.14 \\
\hline $\mathrm{Cs}_{2} \mathrm{O}$ & 0.58 & 0.55 & 0.52 & 0.49 \\
\hline $\mathrm{Fe}_{2} \mathrm{O}_{3}$ & 0.01 & 0.01 & 0.01 & 0.01 \\
\hline $\mathrm{MgO}$ & 0.01 & 0.01 & 0.01 & 0.01 \\
\hline $\mathrm{MnO}_{2}$ & 0.01 & 0.01 & 0.01 & 0.01 \\
\hline $\mathrm{MoO}_{3}$ & 0.59 & 0.56 & 0.53 & 0.50 \\
\hline Sro & 0.42 & 0.40 & 0.38 & 0.36 \\
\hline $\mathrm{P}_{2} \mathrm{O}_{5}$ & 0.75 & 0.71 & 0.68 & 0.64 \\
\hline $\mathrm{SO}_{3}$ & 0.85 & 0.81 & 0.77 & 0.72 \\
\hline $\mathrm{NaCl}$ & 2.29 & 3.30 & 4.95 & 6.59 \\
\hline $\mathrm{NaF}$ & 2.57 & 6.21 & 9.31 & 12.42 \\
\hline $\mathrm{NaI}$ & 0.61 & 0.58 & 0.55 & 0.52 \\
\hline
\end{tabular}


IABLE 3. Oxide Composition of the Original and Modified Remaining. Inventory (RI) Simulants

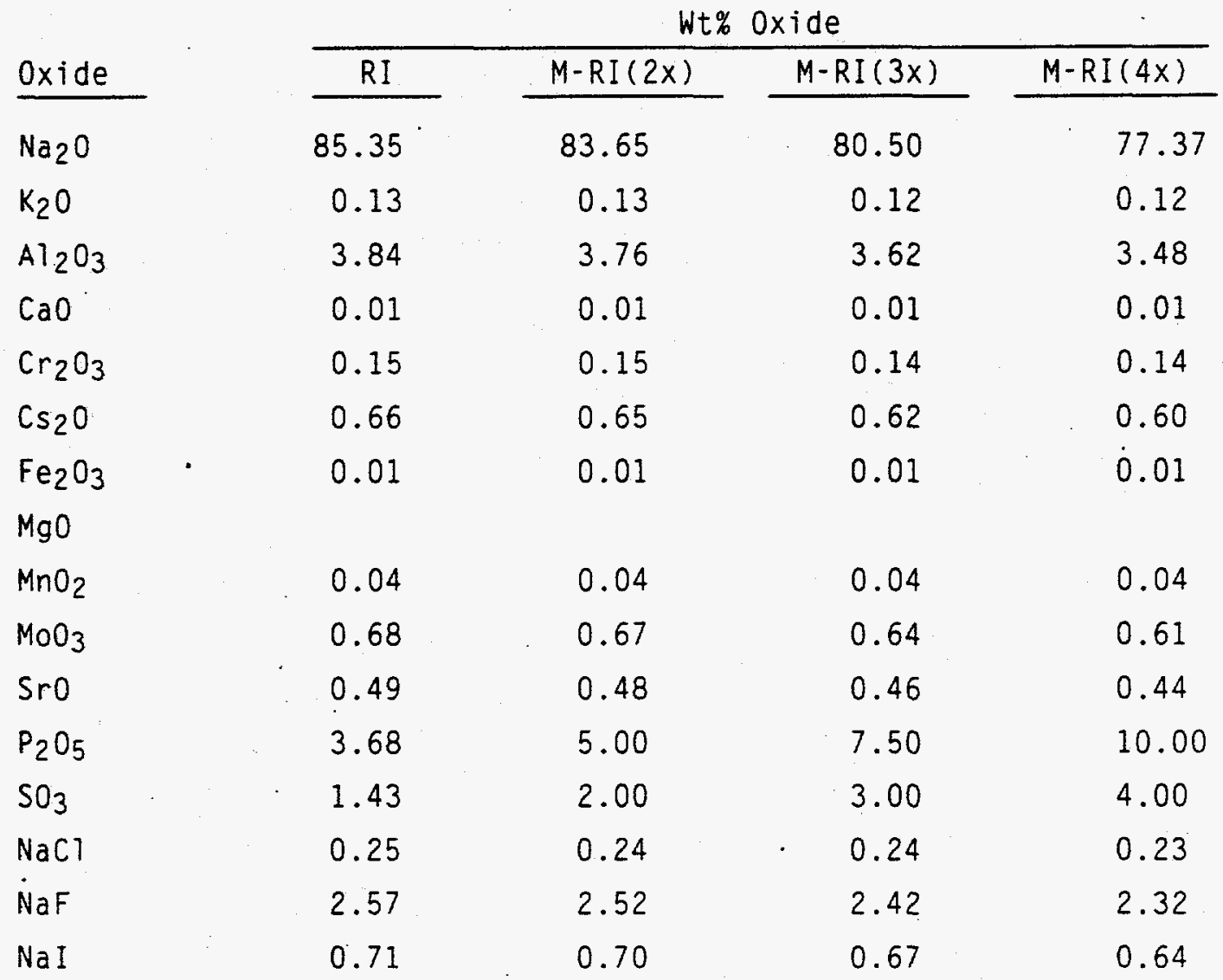

Tables 4 and 5 list the ionic concentrations for the Phase 2 DSSF and RI simulants, respectively. The concentrations are based on $10 \mathrm{M} \mathrm{Na}$ concentrations for the DSSF and RI. The sodium concentrations for the modified simulants were allowed to "float" because of the additional $C l$ and $F$ in the modified DSSF and additional $\mathrm{PO}_{4}$ and $\mathrm{SO}_{4}$ in the modified $\mathrm{RI}$ which were added as sodium salts.

Four batches of the Phase 2 simulants were prepared according to the recipes listed in Tables 6 and 7 using reagent grade chemicals and tap water. During the chemical additions, the solutions were stirred and heated to aid dissolution. After all the chemicals had been added and allowed to dissolve. the volumes were brought to slightly less than one liter through evaporation. The not solutions were then transferred into graduated cylinders, the volumes 
adjusted to one liter, and the densities were determined. After cooling to room temperature, the volumes were readjusted to one liter and the densities were remeasured. The one-liter samples were then transferred to polypropylene jars and maintained at room temperature.

IABLE 4. Ionic Concentration of Phase 2 DSSF simulants

\begin{tabular}{|c|c|c|c|c|}
\hline \multirow[b]{2}{*}{ Species } & \multicolumn{4}{|c|}{ Moles/Liter } \\
\hline & DSSF & $M-\operatorname{DSSF}(2 x)$ & $M-\operatorname{DSSF}(3 x)$ & $M-\operatorname{DSSF}(4 x)$ \\
\hline $\mathrm{Na}$. & $1.00 \mathrm{E}+01$ & $1.04 \mathrm{E}+01$ & $1.09 E+01$ & $1.11 E+01$ \\
\hline K. & $5.00 E-01$ & $4.78 E-01$ & $4.56 E-01$ & $4.33 E-01$ \\
\hline Al & $1.02 E+00$ & $9.72 E-01$ & $9.27 E-01$ & $8.81 E-01$ \\
\hline $\mathrm{Ca}$ & $7.28 E-04$ & $6.96 E-04$ & $6.63 E-04$ & $6.30 E-04$ \\
\hline $\mathrm{Cr}$ & $8.60 E-03$ & $8.21 E-03$ & $7.83 E-03$ & $7.44 E-03$ \\
\hline Cs & $8.40 E-03$ & $8.03 E-03$ & $7.66 \mathrm{E}-03$ & $7.28 E-03$ \\
\hline $\mathrm{Fe}$ & $5.11 E-04$ & $4.89 E-04$ & $4.66 E-04$ & $4.43 E-04$ \\
\hline Mo & $1.67 E-02$ & $1.60 \mathrm{E}-02$ & $1.52 E-02$ & $1.45 E-02$ \\
\hline $\mathrm{Sr}$ & $1.66 \mathrm{E}-02$ & $1.58 \mathrm{E}-02$ & $1.51 E-02$ & $1.43 E-02$ \\
\hline $\mathrm{PO}_{4}$ & $4.32 E-02$ & $4.12 E-02$ & $3.93 E-02$ & $3.74 \mathrm{E}-02$ \\
\hline $\mathrm{SO}_{4}$ & $4.34 E-02$ & $4.14 \mathrm{E}-02$ & $3.95 E-02$ & $3.75 E-02$ \\
\hline $\mathrm{Cl}$ & $1.60 E=01$ & $2.31 E-01$ & $3.49 E-01$ & $4.69 E-01$ \\
\hline$F$ & $2.50 E-01$ & $6.07 E-01$ & $9.16 E-01$ & $1.23 E+00$ \\
\hline $\mathrm{IO}_{4}$ & $1.66 E-02$ & $1.59 E-02$ & $1.51 \mathrm{E}-02$ & $1.44 E-02$ \\
\hline $\mathrm{NO}_{2}$ & $1.70 E+00$ & $1.70 E+00$ & $1.70 E+00$ & $1.70 E+00$ \\
\hline $\mathrm{NO}_{3}$ & $3.20 E+00$ & $2.96 E+00$ & $3.20 E+00$ & $2.96 E+00$ \\
\hline $\mathrm{CO}_{2}$ & $2.70 E-01$ & $2.70 E-01$ & $2.70 E-01$ & $2.70 E-01$ \\
\hline $\mathrm{OH}$ & $3.83 E+00$ & $3.83 E+00$ & $3.83 E+00$ & $3.83 E+00$ \\
\hline TOC & $1.40 E+00$ & $1.40 E+00$ & $1.40 E+00$ & $1.40 E+00$ \\
\hline
\end{tabular}


PVTD-C95-02.03D

IABLE 5. Ionic Concentration of Phase 2 Remaining Inventory (RI) Simulants

Moles/Liter

\begin{tabular}{|c|c|c|c|c|}
\hline Species & RI & $M-R I(2 x)$ & $M=R I(3 x)$ & $M-R I(4 x)$ \\
\hline $\mathrm{Na}$ & $1.00 E+01$ & $1.03 E+01$ & $1.08 E+01$ & $1.14 E+01$ \\
\hline K & $9.77 E-03$ & $9.77 E-03$ & $9.77 E-03$ & $9.96 E=03$ \\
\hline$A 7$ & $2.67 E-01$ & $2.67 E-01$ & $2.67 E-01$ & $2.67 E-01$ \\
\hline $\mathrm{Ca}$ & $6.31 E-04$ & $6.31 E-04$ & $6.31 E-04$ & $6.27 E-04$ \\
\hline $\mathrm{Cr}$ & $6.99 E-03$ & $6.99 E-03$ & $6.99 E-03$ & $6.99 E-03$ \\
\hline Cs & $8.29 E-03$ & $8.29 E-03$ & $8.29 E-03$ & $8.29 E-03$ \\
\hline $\mathrm{Fe}$ & $4.44 E-04$ & $4.44 E-04$ & $4.44 E-04$ & $4.41 E-04$ \\
\hline Mo & $1.67 \mathrm{E}-02$ & $1.67 E-02$ & $1.67 E-02$ & $1.66 E-02$ \\
\hline$S r$ & $1.67 E-02$ & $1.67 E-02$ & $1.67 E-02$ & $1.66 E-02$ \\
\hline $\mathrm{PO}_{4}$ & $1.84 E-01$ & $2.55 E-01$ & $3.97 E-01$ & $5.51 E-01$ \\
\hline $\mathrm{SO}_{4}$ & $6.33 E-02$ & $9.03 E-02$ & $1.41 E-01$ & $1.95 E-01$ \\
\hline Cl & $1.51 E-02$ & $1.51 E-02$ & $1.51 \mathrm{E}-02$ & $1.54 \mathrm{E}-02$ \\
\hline $\mathrm{F}$ & $2.17 E-01$ & $2.17 E-01$ & $2.17 E-01$ & $2.16 E-01$ \\
\hline $\mathrm{IO}_{4}$ & $1.68 E-02$ & $1.68 E-02$ & $1.68 \mathrm{E}-02$ & $1.67 \mathrm{E}-02$ \\
\hline $\mathrm{NO}_{2}$ & $4.30 E-01$ & $4.30 E-0.1$ & $4.30 E-01$ & $4.30 E-01$ \\
\hline $\mathrm{NO}_{3}$ & $6.00 E+00$ & $6.00 E+00$ & $6.00 E+00$ & $6.00 E+00$ \\
\hline $\mathrm{CO}_{2}$ & $8.30 E-02$ & $8.30 E-02$ & $8.30 E-02$ & $8.30 E-02$ \\
\hline $\mathrm{OH}$ & $2.37 E+00$ & $2.37 E+00$ & $2.37 E+00$ & $2.37 E+00$ \\
\hline TOC & $1.80 E-01$ & $1.80 \mathrm{E}-01$ & $1.80 E-01$ & $1.80 E-01$ \\
\hline
\end{tabular}


TABLE 6. Batch Sheet for Phase 2 DSSF Simulants

\begin{tabular}{|c|c|c|c|c|}
\hline \multirow[b]{2}{*}{ Compound } & \multicolumn{4}{|c|}{ grams/Liter } \\
\hline & DSSF & $M-\operatorname{DSSF}(2 x)$ & $M-\operatorname{DSSF}(3 x)$ & $M-\operatorname{DSSF}(4 x)$ \\
\hline $\mathrm{NaNO}_{2}$ & 117.30 & 117.30 & 117.30 & 117.30 \\
\hline $\mathrm{KOH}(85 \%)$ & 33.03 & 31.55 & 30.08 & 28.59 \\
\hline. $\mathrm{SrCl}_{2} \quad 6 \mathrm{H}_{2} \mathrm{O}$ & 4.41 & 4.22 & $4.02^{\circ}$ & 3.82 \\
\hline $\mathrm{NaH}_{2} \mathrm{PO}_{4} \quad \mathrm{H} 2 \mathrm{O}$ & 5.96 & 5.69 & 5.42 & 5.16 \\
\hline $\mathrm{NaIO}_{4}$ & 3.29 & 3.40 & 3.24 & 2.85 \\
\hline $\mathrm{Na}_{2} \mathrm{CO}_{3}$ & 28.62 & 28.62 & 28.62 & 28.62 \\
\hline $\mathrm{NaCl}$ & 7.42 & 11.68 & 18.66 & 25.72 \\
\hline $\mathrm{NaF}$ & 10.50 & 25.47 & 38.45 & 51.59 \\
\hline $\mathrm{Na}_{2} \mathrm{SO}_{4}$ & 6.16 & 5.88 & 5.61 & 5.33 \\
\hline $\mathrm{NaOH}(50 w t \%)$ & 520.08 & 510.73 & 501.21 & 491.57 \\
\hline A) $\left(\mathrm{NO}_{3}\right)_{3} 9 \mathrm{H}_{2} \mathrm{O}$ & 381.65 & 364.62 & 347.63 & 330.42 \\
\hline $\mathrm{Na}_{2} \mathrm{CrO}_{4} \quad 4 \mathrm{H}_{2} \mathrm{O}$ & 1.28 & 0.96 & 0.92 & 1.11 \\
\hline $\mathrm{Na}_{2} \mathrm{MOO}_{4} \quad \mathrm{H}_{2} \mathrm{O}$ & 4.05 & 3.87 & 3.69 & 3.51 \\
\hline $\mathrm{CsNO}_{3}$ & 1.64 & 1.57 & 1.49 & 1.42 \\
\hline $\mathrm{NaNO}_{3}$ & 11.35 & 22.98 & 34.59 & 25.91 \\
\hline $\mathrm{Na}_{4}$ EDTA & 58.27 & 58.27 & 58.27 & 58.27 \\
\hline $\mathrm{Fe}\left(\mathrm{NO}_{3}\right)_{3} \quad 9 \mathrm{H}_{2} \mathrm{O}(\mathrm{a})$ & 0.21 & - & - & 0.18 \\
\hline $\mathrm{Mg}\left(\mathrm{NO}_{3}\right)_{2} \quad 6 \mathrm{H}_{2} \mathrm{O}^{(\mathrm{a})}$ & 0.26 & - & - & 0.22 \\
\hline $\mathrm{Mn}\left(\mathrm{NO}_{3}\right)_{2}(50 \%)$ (a) & 0.16 & - & - & 0.14 \\
\hline
\end{tabular}

(a) Added only to batch 3." 
IABLE 7. Batch Sheet for Phase 2 RI Simulants

\begin{tabular}{|c|c|c|c|c|}
\hline \multirow[b]{2}{*}{ Compound } & \multicolumn{4}{|c|}{ grams/Liter } \\
\hline & RI & $M-R I(2 x)$ & $M-R I(3 x)$ & $M-R I(4 x)$ \\
\hline $\mathrm{NaNO}_{2}$ & 29.67 & 29.67 & 29.67 & 29.67 \\
\hline $\mathrm{KOH}(85 \%)$ & 0.65 & 0.65 & 0.65 & 0.66 \\
\hline $\mathrm{SrCl}_{2} \quad 6 \mathrm{H}_{2} \mathrm{O}$ & 4.47 & 4.47 & 4.47 & 4.43 \\
\hline $\mathrm{NaH}_{2} \mathrm{PO}_{4} \quad \mathrm{H} 2 \mathrm{O}$ & 25.34 & 35.13 & 54.76 & 75.99 \\
\hline $\mathrm{NaIO}_{4}(\mathrm{a})$ & 3.32 & 3.59 & 3.59 & 3.30 \\
\hline $\mathrm{Na}_{2} \mathrm{CO}_{3}$ & 8.80 & 8.80 & 8.80 & 8.80 \\
\hline $\mathrm{NaCl}$ & 0.00 & 0.00 & 0.00 & 0.00 \\
\hline $\mathrm{NaF}$ & 9.10 & 9.10 & 9.10 & 9.07 \\
\hline $\mathrm{Na}_{2} \mathrm{SO}_{4}$ & 8.98 & 12.82 & 19.99 & 27.74 \\
\hline $\mathrm{NaOH}(50$ wt\%) & 284.98 & 296.22 & 318.97 & 343.58 \\
\hline $\mathrm{A}]\left(\mathrm{NO}_{3}\right)_{3} \quad 9 \mathrm{H}_{2} \mathrm{O}$ & 100.07 & 100.07 & 100.07 & 100.08 \\
\hline $\mathrm{Na}_{2} \mathrm{CrO}_{4} \quad 4 \mathrm{H}_{2} \mathrm{O}$ & 1.04 & 0.82 & 0.82 & 1.04 \\
\hline $\mathrm{Na}_{2} \mathrm{MoO}_{4} \quad \mathrm{H}_{2} \mathrm{O}$ & 4.05 & 4.05 & 4.05 & 4.01 \\
\hline $\mathrm{CsNO}_{3}$ & 1.62 & 1.62 & 1.62 & 1.62 \\
\hline $\mathrm{NaNO}_{3}$ & 440.72 & 440.72 & 440.72 & 440.72 \\
\hline $\mathrm{Na}_{4}$ EDTA & .7 .49 & 7.49 & 7.49 & 7.49 \\
\hline $\mathrm{Fe}\left(\mathrm{NO}_{3}\right)_{3} \quad 9 \mathrm{H}_{2} \mathrm{O}(\mathrm{a})$ & 0.18 & - & - & 0.18 \\
\hline $\mathrm{Mg}\left(\mathrm{NO}_{3}\right)_{2} \quad 6 \mathrm{H}_{2} \mathrm{O}(\mathrm{a})$ & 0.00 & - & - & 0.00 \\
\hline $\mathrm{Mn}\left(\mathrm{NO}_{3}\right)_{2}(50 \%)(\mathrm{a})$ & 0.58 & - & - & 0.58 \\
\hline
\end{tabular}

(a) Added only to batch 3 .

The first batches of the simulants were prepared as dilute $(-3 \underline{M} \mathrm{Na})$ solutions and then evaporated to reach a final volume of one liter, resulting in the nominal concentrations listed in Tables 4 and 5 . The dilute solutions would represent the concentrations of wastes exiting the ion exchange process, and the final concentration would be representative of wastes after going through the evaporator. 
Modified DSSF and modified RI were also prepared in concentrated form . (i.e., at the concentrations 1 isted in Tables 4 and 5 ). This procedure would most likely resemble that used by the vendor chosen to produce the simulants for the melter tests.

The third batch of $M-\operatorname{DSSF}(4 x)$ and $M-R I(4 x)$ were prepared as in the first batch. However, during volume reduction, 40-ml samples were taken at various levels of concentration.

\section{REDUCIBLE METALS AND SEMI-VOLATILES SIMULANT ADDITIVES}

Two compositions of various trace metals were prepared for possible inclusion in the Phase 2 melter testing. Certain metals that have been identified in small quantities in the LLW composition data base have the potential for causing processing problems. The metals were selected from inventories of metals greater than 0.5 metric tons. (a)

Because of the uncertainty associated with the concentrations, two metals mixtures containing equal weights of the metals 1 isted in Tables 8 and 9 were selected. The batch sheet used for preparing metals mixture number 1 is listed in Table 8. An alternate, low-hazardous metals mix was also prepared. This mix contained equal concentrations of $\mathrm{Cu}, \mathrm{Zn}, \mathrm{Pb}, \mathrm{Sn}, \mathrm{Cr}, \mathrm{Mn}$. Ni, Mo, Sb, and As (on a metals basis). These metals should demonstrate similar chemical behavior to those in the first mix. but they are usually contained in glass sufficientiy well to pass TCLP criteria, thus minimizing or eliminating the need for disposal as hazardous waste. The batch sheet for the metals mixture number 2 is shown in Table 9 .

The first two batches of the metals mixtures were prepared by adding the chemicals listed in Table 8 and 9 to deionized water while maintaining constant agitation. The final concentration of the solutions/slurries was 100 grams of total compound weight in a volume of one liter. Both mixtures

(a) Shade, J.W. January 5, 1995, Update on Phase 2 Simulants, via cc:Mail. 
contained undissolved or precipitated solids that were easily maintained in suspension, and after settling, they were easily resuspended.

The next step in preparing the mixtures was to make three separate solutions for each mixture. The first solution contained the nitrate salts. The second solution contained the chloride salts, and the third solution contained the remaining salts.

For the first solution for metals mixture number 1 , the nitrate salts of $\mathrm{Bi}, \mathrm{Cd}, \mathrm{Ni}, \mathrm{Pb}$, and $\mathrm{Zn}$ were combined with approximately an equal weight of a I $M$ nitric acid solution. The nitric acid solution was required to completely dissolve the $\mathrm{Bi}\left(\mathrm{NO}_{3}\right)_{3}$. The second solution was prepared by dissolving $\mathrm{SbCl}_{3}$ in a concentrated $\mathrm{HCl}$ solution of equal weight. The $\mathrm{SbCl}_{3}$ cannot be directly dissolved in water because the compound converts to the insoluble antimony oxychloride when contacting water. The third solution was prepared by dissolving $\mathrm{Na}_{2} \mathrm{MOO}_{4} \cdot 2 \mathrm{H}_{2} \mathrm{O}$ in twice its weight of water. There were no undissolved or precipitated solids in these three solutions.

The first solution for metals mixture number 2 was prepared by dissolving the nitrate salts of $\mathrm{Cu}, \mathrm{Zn}, \mathrm{Pb}, \mathrm{Mn}$, and $\mathrm{Ni}$ in a volume of water equal in weight to the total weight of the salts. (Note: Mn was added as a 50 wt\% solution). The second solution contained $\mathrm{SbCl}_{3}$ and $\mathrm{SnCl}_{2}$ dissolved in an equal weight of concentrated $\mathrm{HCl}$. The third solution was prepared by dissolving $\mathrm{Na}_{2} \mathrm{MOO}_{4} \cdot 2 \mathrm{H}_{2} \mathrm{O}, \mathrm{Na}_{2} \mathrm{HASO}_{4} \cdot 7 \mathrm{H}_{2} \mathrm{O}$, and $\mathrm{Na}_{2} \mathrm{CrO}_{4} \cdot 4 \mathrm{H}_{2} \mathrm{O}$ in twice the total compound weight of water. There were no undissolved or precipitated solids in these three solutions. 
IABLE 8. Batch Sheet for Metals Mixture No. 1

\begin{tabular}{llr} 
Metal & \multicolumn{1}{c}{ Compound } & wt\% Comp \\
\hline $\mathrm{Bi}$ & $\mathrm{Bi}\left(\mathrm{NO}_{3}\right)_{3} 5 \mathrm{H}_{2} \mathrm{O}$ & $11.29 \%$ \\
$\mathrm{Cd}$ & $\mathrm{Cd}\left(\mathrm{NO}_{3}\right)_{2} 4 \mathrm{H}_{2} \mathrm{O}$ & $13.35 \%$ \\
$\mathrm{Ni}$ & $\mathrm{Ni}\left(\mathrm{NO}_{3}\right)_{2} .6 \mathrm{H}_{2} \mathrm{O}$ & $24.09 \%$ \\
$\mathrm{~Pb}$ & $\mathrm{~Pb}\left(\mathrm{NO}_{3}\right)_{2}$ & $7.77 \%$ \\
$\mathrm{Zn}$ & $\mathrm{Zn}\left(\mathrm{NO}_{3}\right)_{2} 6 \mathrm{H}_{2} \mathrm{O}$ & $22.13 \%$ \\
$\mathrm{Sb}$ & $\mathrm{SbCl}_{3}$ & $9.11 \%$ \\
$\mathrm{Mo}$ & $\mathrm{Na}_{2} \mathrm{MOO}_{4} 2 \mathrm{H}_{2} \mathrm{O}$ & $12.26 \%$
\end{tabular}

IABLE 9. Batch Sheet for Metals Mixture No. 2

\begin{tabular}{llr} 
Metal & \multicolumn{1}{c}{ Compound } & wt\% Comp. \\
$\mathrm{Cu}$ & $\mathrm{Cu}\left(\mathrm{NO}_{3}\right)_{2} \mathrm{H}_{2} \mathrm{O}$ & $11.57 \%$ \\
$\mathrm{Zn}$ & $\mathrm{Zn}\left(\mathrm{NO}_{3}\right)_{2} 6 \mathrm{H}_{2} \mathrm{O}$ & $13.84 \%$ \\
$\mathrm{~Pb}$ & $\mathrm{~Pb}\left(\mathrm{NO}_{3}\right)_{2}$ & $4.86 \%$ \\
$\mathrm{Mn}$ & $\mathrm{Mn}\left(\mathrm{NO}_{3}\right)_{2}(\mathrm{a})$ & $12.96 \%$ \\
$\mathrm{Ni}$ & $\mathrm{Ni}\left(\mathrm{NO}_{3}\right)_{2} \mathrm{HH}_{2} \mathrm{O}$ & $9.27 \%$ \\
$\mathrm{Sn}$ & $\mathrm{SnCl}_{2}$ & $7.45 \%$ \\
$\mathrm{Sb}$ & $\mathrm{SbCl}_{3}$ & $4.74 \%$ \\
$\mathrm{Mo}$ & $\mathrm{Na}_{2} \mathrm{MOO}_{4} 2 \mathrm{H}_{2} \mathrm{O}$ & $7.23 \%$ \\
$\mathrm{As}$ & $\mathrm{Na}_{2} \mathrm{HASO}_{4} 7 \mathrm{H}_{2} \mathrm{O}$ & $9.82 \%$ \\
$\mathrm{Cr}$ & $\mathrm{Na}_{2} \mathrm{CrO}_{4} 4 \mathrm{H}_{2} \mathrm{O}$ & $18.25 \%$
\end{tabular}

(a) Added as a 50 wt\% solution 


\section{PHYSICAL PROPERTIES}

\section{SETTLED SOLIDS}

The quantity of settled, undissolved or precipitated solids in the Phase 2 simulants was estimated by allowing the freshly prepared solutions/slurries to remain undisturbed in a closed container until a clear supernate was observed and then estimating the total volume of solids by comparing the depth of solids to the total depth of sample. Table 10 lists the estimated amount of settled solids in samples at room temperature and for the same samples after heating to $\sim 75^{\circ} \mathrm{C}$. The RI and $M-R I$ samples had the most solids, ranging between 19 and 23 vol\% for the RI sample and between 14 and 58 vol\% for the $M$ RI samples. After cooling from $75^{\circ} \mathrm{C}$ to room temperature the M-RI samples appeared "gelatinous" as a network of crystals formed throughout the sample. The crystals are likely sodium phosphate because of the high levels of sodium and phosphate present in the M-RI simulants and because of the high temperature dependence on the solubility of sodium phosphates. 
IABLE 10. Estimated Volume Percent Settled Solids

\begin{tabular}{|c|c|c|c|}
\hline \multirow[b]{2}{*}{ Simulant } & \multicolumn{2}{|c|}{ Solids, vol\% } & \multirow[b]{2}{*}{$\operatorname{Batch}^{(b)}$} \\
\hline & $\overline{R T(a)}$ & $75^{\circ} \mathrm{C}$ & \\
\hline DSSF & 7 & 2 & 1 \\
\hline$M-\operatorname{DSSF}(2 x)$ & 7 & 6 & 3 \\
\hline$M-\operatorname{DSSF}(3 x)$ & 9 & 6 & 3 \\
\hline$M-\operatorname{DSSF}(4 x)$ & 8 & 6 & 1 \\
\hline$M-\operatorname{DSSF}(4 x)$ & 16 & 14 & 2 \\
\hline RI & 23 & 19 & 1 \\
\hline$M-R I(2 x)$ & 28 & 14 & 3 \\
\hline$M-R I(3 x)$ & 40 & 22 & 3 \\
\hline$M-R I(4 x)$ & 58 & 40 & 1 \\
\hline$M-R I(4 x)$ & 46 & 37 & 2 \\
\hline
\end{tabular}

(a) RT $=$ room temperature

(b). Batch 1 was prepared dilute and then concentrated:

Batches 2 and 3 were prepared concentrated.

An important property of slurries is the ability to resuspend the solids once they have settled in order to obtain a uniform feed to the vitrification facility. A qualitative evaluation of the "resuspendability" of the solids in the simulants was done by allowing the solids to settle in a 1-L polypropylene bottle overnight and then slowly turning the bottles end-over-end several times, each time inspecting the bottom for the presence of remaining solids. The solids in all the samples, except the room temperature M-OSSF $(4 x)$ sample from Batch 2, were resuspended by only a few rotations of the sample. The M$\operatorname{DSSF}(4 \mathrm{x})$ sample had to be shaken vigorously to resuspend the settled solids: Based on these observations, it appears that the solids in all the simulants could be resuspended by moderate to vigorous agitation.

\section{DENSITY}

Density of the solutions/slurries, i.e., of the total sample, was measured by weighing a known volume within a graduated cylinder. The density of the 
supernates was determined by weighing a 100-ml sample in a volumetric flask at room temperature. Table 11 summarizes the density results. The densities of the slurries at room temperature were generally about 2 to $3 \%$ higher than at the elevated temperatures.

\section{TABLE 11. Density of Phase 2 Simulants}

\begin{tabular}{|c|c|c|c|c|}
\hline \multirow[b]{2}{*}{ Simulant } & \multicolumn{3}{|c|}{ Density, $\mathrm{g} / \mathrm{cm}^{3}$} & \multirow[b]{2}{*}{ Batch (c) } \\
\hline & Supernate & Total(a) & Total $\left({ }^{\circ} \mathrm{C}\right)^{(b)}$ & \\
\hline DSSF & 1.445 & 1.46 & $1.42(71)$ & 1 \\
\hline$M-\operatorname{DSSF}(4 x)$ & 1.447 & 1.47 & $1.44(64)$ & 1 \\
\hline$M-\operatorname{DSSF}(4 x)$ & 1.443 & 1.48 & $1.44(70)$ & 2 \\
\hline$M-\operatorname{DSSF}(3 x)$ & $N D^{(d)}$ & 1.47 & $1.45 \quad(85)$ & 4 \\
\hline$M-\operatorname{DSSF}(2 x)$ & ND & 1.47 & $1.43(84)$ & 4 \\
\hline RI & 1.393 & 1.45 & $1.44(75)$ & 1 \\
\hline$M-R I(2 x)$ & ND & 1.48 & $1.43(85)$ & 4 \\
\hline$M-R I(3 x)$ & ND & 1.50 & $1.46 \cdot(82)$ & 4 \\
\hline$M-R I(4 x)$ & 1.397 & 1.52 & $1.49(65)$ & $i$ \\
\hline$M-R I(4 x)$ & 1.403 & 1.52 & $1.49(75)$ & 2 \\
\hline
\end{tabular}
(a) Measured at room temperature
(b) Measured at the temperature in parentheses
(c) Batch 1 was prepared dilute and then concentrated; Batches 2 and 3 were prepared concentrated.
(d) $N D=$ Not Determined

\section{VISCOSITY}

Viscosity of the simulants was measured using a Fann viscometer. The measured values are shown in Table 12. The nature of the solids in the RI simulants did not allow for viscosity measurements on the total samples because the size of some of the solid particles was larger than the gap size in the viscometer and because the solids settled out very quickly in the viscometer cup. However, based on a qualitative evaluation of the simulants, the apparent viscosities of the slurries should be sufficiently low to allow adequate handling and transport in the melter vendor processes. 
IABLE 12. Viscosity of Phase 2 Simulants

\begin{tabular}{|c|c|c|c|}
\hline \multirow[b]{2}{*}{ Simulant } & \multicolumn{2}{|c|}{ Viscosity, $c P(a)$} & \multirow[b]{2}{*}{ Batch } \\
\hline & Supernate & Slurry & \\
\hline DSSF & .15 & 16 & 1 \\
\hline$M-\operatorname{DSSF}(2 x)$ & 16 & 18 & 4 \\
\hline$M-\operatorname{DSSF}(3 x)$ & 16 & 19 & 4 \\
\hline$M-\operatorname{DSSF}(4 x)$ & 16 & 17 & 1 \\
\hline$M-\operatorname{DSSF}(4 x)$ & 16 & 18 & 2 \\
\hline RI & 8 & $N D(b)$ & 1 \\
\hline$M-R I(2 x)$ & 7 & ND & 3 \\
\hline$M-R I(3 x)$ & 8 & ND & 3 \\
\hline$M-R I(4 x)$ & 8 & ND & 1 \\
\hline$M-R I(4 x)$ & 8 & ND & 2 \\
\hline
\end{tabular}

(a) Values at a shear rate of $511 \mathrm{~s}^{-1}$

(b) $N D=$ Not Determined because of the presence of large crystalline solids

\section{CHEMICAL PROPERTIES}

Samples of the simulants were dried at $105^{\circ} \mathrm{C}-120^{\circ} \mathrm{C}$ in a vacuum oven for several. days to determine evaporable water or moisture content. Table 13 compares results calculated from the nominal composition and from the measured density, and the experimental results measured after allowing the samples to cool in a desiccator. The experimental and calculated values are in general agreement, with an average moisture content of about $50 \%$ by weight. The larger experimental values for the RI samples are likely caused by the difficulty in obtaining truly representative specimens from the simulant samples. The large quantity of solids, and their rapid settling rate resulted in specimens that contained less undissolved solids, resulting in a higher experimentally determined moisture contents. 
TABLE 13. Moisture Content of Phase 2 Simulants

\begin{tabular}{|c|c|c|c|}
\hline \multirow[b]{2}{*}{ Simulant } & \multicolumn{2}{|c|}{ Moisture Content, wt\% } & \multirow[b]{2}{*}{ Batch } \\
\hline & Calculated & Experimental & \\
\hline DSSF & 53.6 & 50.0 & 1 \\
\hline$M-\operatorname{DSSF}(2 x)$ & 52.7 & 47.7 & 4 \\
\hline$M-\operatorname{DSSF}(3 x)$ & 51.6 & 48.7 & 4 \\
\hline$M-\operatorname{DSSF}(4 x)$ & 50.4 & 48.9 & 1 \\
\hline$M-\operatorname{DSSF}(4 x)$ & 50.7 & 48.9 & 2 \\
\hline RI & 50.8 & $52: 5$ & 1 \\
\hline$M-R I(2 x)$ & 50.8 & 52.0 & 4 \\
\hline$M-R I(3 x)$ & 49.4 & 51.6 & 4 \\
\hline$M-R I(4 X)$ & 47.9 & 52.5 & 1 \\
\hline$M-R I(4 x)$ & 47.9 & 52.7 & 2 \\
\hline
\end{tabular}

Chemical analyses were conducted on selected simulants to compare the analyzed concentrations with the target values. Inductively coupled argon plasma emission. spectrometry (ICP) was conducted with a Thermo Jarrell-Ash Model 61E spectrometer according to Method APSL-14. The solutions were acidified using 2 vol\% nitric acid. Anion concentrations were measured using a Dionex Series $4000 i$ ion chromatograph according to procedure PNL-ALO-212 Rev. 1. Carbon analyses was conducted using a Xertex-Dohrmann Model DC-80 carbon analyzer according to procedure PNL-ALO-382.1 Rev. 0 . The free hydroxide content was determined by titration. A summary of the analytical results are shown in Tables 14 through 19.

Table 14 compares the nominal composition of DSSF and modified DSSF and the analyzed composition of the supernates from the samples. It should be noted that the analyzed Al values may be higher than actual because the samples were stored in plastic vials with aluminum-lined caps. The concentration of several of the analyzed species are considerably below the nominal composition, indicating that these species either precipitated from solution. or were not completely dissolved. These included $\mathrm{Cr}, \mathrm{PO}_{4}, \mathrm{SO}_{4}$, and $\mathrm{Sr}$. 
TABLE 14. Nominal and Analyzed Chemical Composition of DSSF and M-DSSF., mg/L (Analyzed Composition is of the Supernate only).

\begin{tabular}{|c|c|c|c|c|c|}
\hline \multirow[b]{2}{*}{ Ion } & \multicolumn{2}{|c|}{ DSSF. } & \multicolumn{3}{|c|}{$M-\operatorname{DSSF}(4 x)$} \\
\hline & Nominal & Batch 1 & Nominal & Batch 1 & Batch 2 \\
\hline$A 1$ & 27.450 & 27.015 & 23.765 & 22.320 & 24,910 \\
\hline $\mathrm{Ca}$ & 29 & 11 & 25 & $<5$ & $<5$ \\
\hline $\mathrm{Cl}$ & 5.673 & 5.056 & 16.616 & 15.910 & 15,869 \\
\hline $\mathrm{CO}_{3}$ & 16.200 & 25.280 & 16.200 & 15,910 & $18: 750$ \\
\hline $\mathrm{Cr}$ & 447 & 275 & 387 & 214 & 244 \\
\hline$F$ & 4.749 & $N D(c)$ & 23,344 & ND & - ND \\
\hline$k$ & 19.562 & 19,214 & 16.936 & 15.716 & 16,814 \\
\hline Mo & 1.606 & 1.552 & 1,390 & 1.309 & 1,411 \\
\hline $\mathrm{Na}$ & 229,900 & 213.970 & 254.760 & 209.330 & 226,280 \\
\hline $\mathrm{NO}_{2}$ & 78,200 & 76,560 & 78.200 & 73,770 & 79.340 \\
\hline $\mathrm{NO}_{3}$ & 198,400 & 187,800 & 183,497 & 188,050 & 187.500 \\
\hline $\mathrm{OH}$ & 65.067 & 46.660 & 65,110 & 51.640 & 46,600 \\
\hline $\mathrm{PO}_{4}$ & 4.099 & $(580)$ & 3,549 & $(870)$ & (580) \\
\hline $\mathrm{SO}_{4}$ & 4.166 & 1,730 & 3.606 & 1,740 & 1.730 \\
\hline$S r$ & 1.450 & 564 & 1,256 & 459 & 566 \\
\hline TOC & 16.800 & 15,601 & 16,800 & 16,060 & 15.440 \\
\hline
\end{tabular}

(a) Values in parentheses are close to the analytical detection limit (b) "Less-than" values are the analytical detection limit

(c) ND $=$ Not Determined

Table 15 compares the nominal composition of RI and modified RI and the analyzed composition of the supernates from the samples. These samples had considerable quantities of undissolved solids as discussed above. Based on the $\mathrm{PO}_{4}$ results, it appears that most of the $\mathrm{PO}_{4}$ precipitated, probably as a sodium phosphate. Sulfate, $\mathrm{Cr}$, and $\mathrm{Sr}$ are also lower in concentration than the nominal, overall concentrations. The analyzed carbonate concentrations are considerably higher and the hydroxide concentrations lower than desired. due possibly to conversion of $\mathrm{OH}$ to $\mathrm{CO}_{3}$ by atmospheric $\mathrm{CO}_{2}$ during agitation and volume reduction. 
Tables 16 and 17 show the analyzed concentrations of species of modified DSSF and modified RI at different stages of concentration. The modified DSSF samples showed a fairly uniform increase in concentration of all species in the supernates as the samples were concentrated. The modified DSSF sample at a nominal $10 \mathrm{M}$ Na concentration (last column of Table 16) did not indicate the degree of precipitation as suggested by the compositions of the previous modified DSSF supernates (see Table 14 ), suggesting that the precipitation may be kinetically controlled, i.e., occurring over time.

Tables 18 and 19 compare the nominal total metal composition of the two metals mixtures to the analyzed composition of the mixture supernates. As discussed above, considerable precipitation occurred in these mixtures, and the data in the tables suggest which species are present in the supernate and which precipitated. Table 18 shows that, within experimental and/or analytical errors, the $\mathrm{Cd}, \mathrm{Ni}$, and $\mathrm{Zn}$ remained in solution in the metals mixture number 1 . while most of the other metals precipitated. Similariy, in the metals mixture number 2 , the $\mathrm{Cu}, \mathrm{Zn}$. $\mathrm{Mn}$, and $\mathrm{Ni}$ appeared to remain in solution, while $S n$ and Mo were almost entirely precipitated. About half the $\mathrm{Pb}$ and two thirds of the $\mathrm{Cr}$ remained in solution. Although Sb was not analyzed, based on observation during preparation of the mixtures, it is believed that nearly all of the Sb would be present in the solid phase. 
IABLE 15. Nominal and Analyzed Chemical Composition of RI and M-RI, mg/L (Analyzed Composition is of the Supernate only).

\begin{tabular}{|c|c|c|c|c|c|}
\hline \multirow[b]{2}{*}{ Ion } & \multicolumn{2}{|c|}{$R I$} & \multicolumn{3}{|c|}{$M-R I(4 x)$} \\
\hline & Nominal & Batch 1 & Nominal & Batch 1 & Batch 2 \\
\hline$A T$ & 7.197 & 8.504 & 7.198 & 10.012 & 8,258 \\
\hline $\mathrm{Ca}$ & 25 & $<5$ & 25 & $<5$ & $<5$ \\
\hline $\mathrm{Cl}$ & 537 & 696 & 545 & 783 & 800 \\
\hline $\mathrm{CO}_{3}$ & 4.980 & 15.320 & 4.980 & 6.990 & 19.650 \\
\hline $\mathrm{Cr}$ & 363 & 234 & 364 & 291 & 281 \\
\hline Cs & 1,102 & $N D(c)$ & 1.102 & ND & ND \\
\hline$F$ & 4.118 & ND & 4.103 & ND & ND \\
\hline$k$ & 382 & $<150$ & 389 & $<150$ & $<150$ \\
\hline Mo & 1.605 & 1,730 & 1.589 & 2.040 & 1,985 \\
\hline $\mathrm{Na}$ & 229.900 & 198,430 & 261.218 & 209.650 & 204,750 \\
\hline $\mathrm{NO}_{2}$ & 19.780 & 20.89 .0 & 19.780 & 23.760 & 25,260 \\
\hline $\mathrm{NO}_{3}$ & 372.000 & 334.200 & 372,000 & 279.500 & 294.700 \\
\hline $\mathrm{OH}$ & 40,315 & 33.140 & 40,290 & 42.760 & 33.400 \\
\hline $\mathrm{PO}_{4}$ & 17,439 & $(560)$ & 52.300 & 2.930 & 3.230 \\
\hline $\mathrm{SO}_{4}$ & 6.077 & 1.950 & 18,760 & 15.370 & 11.930 \\
\hline$s r$ & 1.467 & 553 & 1,454 & 137 & 237 \\
\hline TOC & 2.160 & 2.500 & 2.160 & 2.660 & 2.250 \\
\hline
\end{tabular}

(a) Values in parentheses are close to the analytical detection limit (b) "Less-than" values are the analytical detection limit

(c) ND = Not Determined 
TABLE 16. Analyzed Chemical Composition of M-DSSF(4x) Supernates at Various Stages of Concentration. $\mathrm{mg} / \mathrm{L}$

Approximate Concentration Factor(a)

Ion

A1

$\mathrm{Ca}$

$\mathrm{Cl}$

$\mathrm{CO}_{3}$

$\mathrm{Cr}$

Cs

$\mathrm{F}$

$\mathrm{Fe}$

$\mathrm{IO}_{4}$

K

$\mathrm{Mg}$

$\mathrm{Mn}$

Mo

$\mathrm{Na}$

$\mathrm{NO}_{2}$

$\mathrm{NO}_{3}$

$\mathrm{OH}$

$\mathrm{PO}_{4}$

$\mathrm{SO}_{4}$

Sr

TOC

\begin{tabular}{|c|c|c|c|}
\hline 0.27 & 0.42 & 0.67 & 1.00 \\
\hline 5.945 & 10,006 & 16,603 & 24,344 \\
\hline 19 & 27 & 46 & 37 \\
\hline 4.064 & 6,271 & 10.328 & 14.510 \\
\hline 5.081 & 7.839 & 15.492 & 25.393 \\
\hline 67 & 102 & 153 & 235 \\
\hline$N D^{(b)}$ & ND & NO & ND \\
\hline ND & ND & ND & ND \\
\hline 5 & 1 & 7 & 17 \\
\hline ND & ND & ND & ND \\
\hline
\end{tabular}

$$
4,656
$$

7.073

10,816

16,133

$<12$

$<12$

$<12$

$<1$

$<1$

579

<1

<1

380

100,700

873

1,320

$$
67.400
$$

31.360

133,000

224,000

20,320

77,180

51.640

76.900

20.092

129.100

192.980

$$
13.630
$$

1,568

30.730

46.870

960

1.447

1,549

2,031

1,005

2.324

3.337

154

247

378

553

4.290

4,462

10.840

15.530

(a) Concentration Factor is the concentration relative to a 10 M Na solution (b) $N D=$ Not Determined

(c) "Less-Than" values are detection limits 
IABLE 17. Analyzed Chemical Composition of M-RI(4x) Supernates at Various - Stages of Concentration. mg/L

\begin{tabular}{|c|c|c|c|}
\hline \multicolumn{4}{|c|}{ Approximate Concentration Factor(a) } \\
\hline 0.27 & 0.42 & 0.67 & 1.00 \\
\hline 3,810 & 4,240 & 6.120 & 9,230 \\
\hline$<2^{(b)}$ & $<2$ & $<2$ & $<2$ \\
\hline 211 & 346 & 504 & 843 \\
\hline 2,220 & 2,990 & 5.970 & 2,180 \\
\hline 60 & 93 & 141 & 260 \\
\hline$N D(c)$ & ND & ND & ND \\
\hline ND & ND & ND & ND \\
\hline 1 & 3 & 8 & 12 \\
\hline ND & ND & ND & ND \\
\hline$<60$ & $<60$ & $<60$ & 123 \\
\hline$<12$ & $<12$ & $<12$ & $<12$ \\
\hline$<1$ & $<1$ & $<1$ & $<1$ \\
\hline 455 & 672 & 1.010 & 1.840 \\
\hline 70,900 & 100,300 & 132.700 & 164,600 \\
\hline 5.430 & 8.600 & 13.800 & 26,150 \\
\hline 98,610 & 167,200 & 252,100 & 290,600 \\
\hline 9.040 & 14.210 & 24.820 & 41,990 \\
\hline 8,860 & 7.160 & 14,600 & 11,040 \\
\hline 4.880 & 7,760 & 9.020 & 7,270 \\
\hline 21 & 37 & 37 & 69 \\
\hline 665 & 955 & 1.330 & 581 \\
\hline
\end{tabular}

(a) Concentration Factor is the concentration relative to a $10 \mathrm{M} \mathrm{Na}$ solution (c) $\quad$ ND $=$ Not Determined

(b) "Less-Than" values are detection limits 
IABLE 18. Nominal and Analyzed Composition of Metals Mixture 1. Supernate

\begin{tabular}{|c|c|c|}
\hline \multirow[b]{2}{*}{ Metal } & \multicolumn{2}{|c|}{ Composition, mg/L } \\
\hline & Nominal & Analyzed \\
\hline$B i$ & 4817 & 59.7 \\
\hline $\mathrm{Cd}$ & 4817 & 4518 \\
\hline Mo & 4817 & 7.1 \\
\hline $\mathrm{Ni}$ & 4817 & 4669 \\
\hline $\mathrm{Pb}$ & 4817 & 1510 \\
\hline $\mathrm{Sb}$ & 4817 & $N D^{(a)}$ \\
\hline$Z n$ & 4817 & 4488 \\
\hline
\end{tabular}

(a) ND $=$ Not Determined

TABLE 19. Nominal and Analyzed Composition of Metals Mixture 2 Supernate

\begin{tabular}{|c|c|c|}
\hline \multirow[b]{2}{*}{ Metal } & \multicolumn{2}{|c|}{ Composition, $\mathrm{mg} / \mathrm{L}$} \\
\hline & Nominal & Analyzed \\
\hline $\mathrm{Cu}$ & 3109 & 3204 \\
\hline$Z n$ & 3109 & 2847 \\
\hline $\mathrm{Pb}$ & 3109 & 1502 \\
\hline$S n$ & 3109 & 5.5 \\
\hline $\mathrm{Cr}$ & 3109 & 2028 \\
\hline$M n$ & 3109 & 3290 \\
\hline $\mathrm{Ni}$ & 3109 & 2914 \\
\hline Mo & 3109 & 272 \\
\hline $\mathrm{Sb}$ & 3109 & No(a) \\
\hline As & 3109 & ND \\
\hline
\end{tabular}

(a) $\quad$ ND $=$ Not Determined 
PVTD-C95-02.03D

\section{RECOMMENDED PROCEDURE FOR PHASE 2 LLW SIMULANT PREPARATION}

The following procedure is recommended for preparing DSSF. M-DSSF $(4 x)$, RI, and M-RI (4x) LLW simulants for the Phase 2 melter vendor tests. Start with water at approximately 30 vol\%, of the final solution volume required. Add the appropriate amounts of the following compounds (solutions) in the order listed to the water while maintaining constant, moderate agitation (note: the solution may be heated to aid dissolution):

\begin{tabular}{|c|c|c|c|c|}
\hline \multirow[b]{2}{*}{ Compound } & \multicolumn{4}{|c|}{ grams/Liter } \\
\hline & DSSF & RI & $M-\operatorname{DSSF}(4 x)$ & $M-R I(4 x)$ \\
\hline $\mathrm{NaNO}_{2}$ & 117.30 & 29.67 & 117.30 & 29.67 \\
\hline $\mathrm{KOH}(85 \%)$ & 33.03 & 0.65 & 28.59 & 0.66 \\
\hline $\mathrm{SrCl}_{2} \cdot 6 \mathrm{H}_{2} \mathrm{O}$ & 4.41 & 4.47 & 3.82 & 4.43 \\
\hline $\mathrm{NaH}_{2} \mathrm{PO}_{4} \cdot \dot{\mathrm{H}} 2 \mathrm{O}$ & 5.96 & 25.34 & 5.16 & 75.99 \\
\hline $\mathrm{NaIO}_{4}$ & 3.29 & 3.32 & 2.85 & 3.30 \\
\hline $\mathrm{NaCl}$ & 7.42 & 0.00 & 25.72 & 0.00 \\
\hline $\mathrm{NaF}$ & 10.50 & 9.10 & 51.59 & 9.07 \\
\hline $\mathrm{Na}_{2} \mathrm{SO}_{4}$ & 6.16 & 8.98 & 5.33 & 27.74 \\
\hline $\mathrm{NaOH}(50$ wt\% & 520.08 & 284.98 & 491.57 & 343.58 \\
\hline $\mathrm{Na}_{2} \mathrm{CO}_{3}$ & 28.62 & 8.80 & 28.62 & 8.80 \\
\hline $\mathrm{Al}\left(\mathrm{NO}_{3}\right)_{3} \cdot 9 \mathrm{H}_{2} \mathrm{O}$ & 381.65 & 100.07 & 330.42 & 100.08 \\
\hline $\mathrm{Na}_{2} \mathrm{CrO}_{4} \cdot 4 \mathrm{H}_{2} \mathrm{O}$ & 1.28 & 1.04 & 1.11 & 1.04 \\
\hline $\mathrm{Na}_{2} \mathrm{MOO}_{4} \cdot \mathrm{H}_{2} \mathrm{O}$ & 4.05 & 4.05 & 3.51 & 4.01 \\
\hline $\mathrm{CsNO}_{3}$ & 1.64 & 1.62 & 1.42 & 1.62 \\
\hline $\mathrm{NaNO}_{3}$ & 11.35 & 440.72 & 25.91 & 440.72 \\
\hline $\mathrm{Na}_{4}$ EDTA & 58.27 & 7.49 & 58.27 & 7.49 \\
\hline
\end{tabular}

Add a minimum amount of water to completely dissolve the following compounds prior to adding to the main solution:
$\mathrm{Fe}\left(\mathrm{NO}_{3}\right)_{3} \cdot 9 \mathrm{H}_{2} \mathrm{O}$
0.21
0.18
0.18
0.18
$\mathrm{Mg}\left(\mathrm{NO}_{3}\right)_{2} \cdot 6 \mathrm{H}_{2} \mathrm{O}$
0.26
0.00
0.22
0.00
$\mathrm{Mn}\left(\mathrm{NO}_{3}\right)_{2}(50 \%$ sol'n) 0.16
0.58
0.14
0.58 
When all the compounds have been added and no further dissolution appears to be occurring, allow the solution to $\operatorname{cool}$ to room temperature $\left(\sim 20\right.$ to $\left.25^{\circ} \mathrm{C}\right)$ and adjust the volume with water to the required level.

When using solutions as a substitute for the dry chemicals, the initial volume of water may need to be decreased to ensure that the final volume does not exceed the desired volume. If aluminum nitrate solution is used, it is recommended that this solution be added to the $50 \% \mathrm{NaOH}$ solution first, and then the remaining ingredients added to this solution. again in the order listed above.

Based on the heterogeneous nature of the resulting simulants (i.e.. the large amount of solids), obtaining representative samples for confirmatory analyses from large batches is very difficult. It is therefore recommended that the individual chemicals be analyzed to determine purity and the analyzed values be used for adjustment of amounts. The quantity added to the batch should then be used for determining total composition and acceptability of the simulants for use in the Phase 2 melter tests.

\section{RECOMMENDED PROCEDURE FOR PHASE 2 METALS MIXTURES PREPARATION}

The two metals mixtures can either be prepared as individual mixtures or as three separate solutions for each composition. Because of the chemicals used for the individual metals, precipitation occurs when all the chemicals are mixed together. If a single solution/slurry is satisfactory, or desired, the metals mixtures should be prepared by.mixing the chemicals 1isted below in sufficient water to allow the solids that precipitate to be easily resuspended. (Note: in the development studies, the solutions/slurries were mixed at a total compound weight of 100 grams in a total volume of one liter.) 
Metals Mixture Number 1 (Single Solution/Slurry):

\begin{tabular}{llr} 
Metal & \multicolumn{1}{c}{ Compound } & wt\% Comp. \\
$\mathrm{Bi}$ & $\mathrm{Bi}\left(\mathrm{NO}_{3}\right)_{3} \cdot 5 \mathrm{H}_{2} \mathrm{O}$ & $11.29 \%$ \\
$\mathrm{Cd}$ & $\mathrm{Cd}\left(\mathrm{NO}_{3}\right)_{2} \cdot 4 \mathrm{H}_{2} \mathrm{O}$ & $13.35 \%$ \\
$\mathrm{Ni}$ & $\mathrm{Ni}\left(\mathrm{NO}_{3}\right)_{2} \cdot 6 \mathrm{H}_{2} \mathrm{O}$ & $24.09 \%$ \\
$\mathrm{~Pb}$ & $\mathrm{~Pb}\left(\mathrm{NO}_{3}\right)_{2}$ & $7.77 \%$ \\
$\mathrm{Zn}$ & $\mathrm{Zn}\left(\mathrm{NO}_{3}\right)_{2} \cdot 6 \mathrm{H}_{2} \mathrm{O}$ & $22.13 \%$ \\
$\mathrm{Sb}$ & $\mathrm{SbCl}_{3}$ & $9.11 \%$ \\
$\mathrm{Mo}$ & $\mathrm{Na}_{2} \mathrm{MOO}_{4} \cdot 2 \mathrm{H}_{2} \mathrm{O}$ & $12.26 \%$
\end{tabular}

Metals Mixture Number 2 (Single Solution/Slurry):

\begin{tabular}{llr} 
Metal & \multicolumn{1}{c}{ Compound } & wt\% Comp \\
$\mathrm{Cu}$ & $\mathrm{Cu}\left(\mathrm{NO}_{3}\right)_{2} \cdot 3 \mathrm{H}_{2} \mathrm{O}$ & $11.57 \%$ \\
$\mathrm{Zn}$ & $\mathrm{Zn}\left(\mathrm{NO}_{3}\right)_{2} \cdot 6 \mathrm{H}_{2} \mathrm{O}$ & $13.84 \%$ \\
$\mathrm{~Pb}$ & $\mathrm{~Pb}\left(\mathrm{NO}_{3}\right)_{2}$ & $4.86 \%$ \\
$\mathrm{Mn}$ & $\mathrm{Mn}\left(\mathrm{NO}_{3}\right)_{2}$ & $12.96 \%$ \\
$\mathrm{Ni}$ & $\mathrm{Ni}\left(\mathrm{NO}_{3}\right)_{2} \cdot 6 \mathrm{H}_{2} \mathrm{O}$ & $9.27 \%$ \\
$\mathrm{Sn}$ & $\mathrm{SnCl}_{2}$ & $7.45 \%$ \\
$\mathrm{Sb}$ & $\mathrm{SbCl}_{3}$ & $4.74 \%$ \\
$\mathrm{Mo}$ & $\mathrm{Na}_{2} \mathrm{MOO}_{4} \cdot 2 \mathrm{H}_{2} \mathrm{O}$ & $7.23 \%$ \\
AS & $\mathrm{Na}_{2} \mathrm{HASO}_{4} \cdot 7 \mathrm{H}_{2} \mathrm{O}$ & $9.82 \%$ \\
$\mathrm{Cr}$ & $\mathrm{Na}_{2} \mathrm{CrO}_{4} \cdot 4 \mathrm{H}_{2} \mathrm{O}$ & $18.25 \%$
\end{tabular}

Three individual solutions for each metals mixture can also be prepared. This approach results in concentrated solutions, devoid of undissolved or precipitated solids.

For the first solution for metals mixture number 1 , the nitrate salts of $\mathrm{Bi}, \mathrm{Cd}, \mathrm{Ni}, \mathrm{Pb}$, and $\mathrm{Zn}$ are combined with approximately an equal weight of a 1 $M$ nitric acid solution. The nitric acid solution is required to completely dissolve the $\mathrm{Bi}\left(\mathrm{NO}_{3}\right)_{3}$ : the other nitrate salts can be dissolved in pure water. The second solution is prepared by dissolving $\mathrm{SbCl}_{3}$ in a concentrated $\mathrm{HCl}$ 
solution of equal weight. The $\mathrm{SbCl}_{3}$ cannot be directly dissolved in water because the compound is converted to the insoluble antimony oxychloride. The third solution is prepared by dissolving $\mathrm{Na}_{2} \mathrm{MOO}_{4} \cdot 2 \mathrm{H}_{2} \mathrm{O}$ in twice its weight of water.

The first solution for metals mixture number 2 is prepared by dissolving the nitrate salts of $\mathrm{Cu}, \mathrm{Zn}, \mathrm{Pb}, \mathrm{Mn}$, and $\mathrm{Ni}$ in a volume of water equal in weight to the total weight of the salts. (Note: Mn was added as a 50 wt\% solution). The second solution contains $\mathrm{SbCl}_{3}$ and $\mathrm{SnCl}_{2}$ dissolved in an equal weight of concentrated $\mathrm{HCl}$. The third solution is prepared by dissolving $\mathrm{Na}_{2} \mathrm{MOO}_{4} \cdot 2 \mathrm{H}_{2} \mathrm{O}, \mathrm{Na}_{2} \mathrm{HASO}_{4} \cdot 7 \mathrm{H}_{2} \mathrm{O}$, and $\mathrm{Na}_{2} \mathrm{CrO}_{4} \cdot 4 \mathrm{H}_{2} \mathrm{O}$ in twice the total compound weight of water. 


\section{REFERENCES}

Hendrickson, D. W. and J. M. Conner. 1994. Grout Treatment Facility Waste Feed Projections. WHC-SD-WM-TI-528, Rev. 1. Westinghouse Hanford Company. Richland. Washington.

Lokken, R. 0. 1995. Low-Level Tank Waste Simulant Data Base. PVTD-C95-

02.03J. Pacific Northwest Laboratory, Richland, Washington.

Lokken, R. O. and P. F. C. Martin. 1994. Makeup Procedures and

Characterization Data for Simulated Low-Level Wastes. TDD-94-151, C94-21.04E, Pacific Northwest Laboratory, Richland, Washington.

Shade, J. W. 1994. Waste Simulant Development for Evaluation of LWW Melter System Technology. WHC-SD-WM-TI-624. Westinghouse Hanford Company, Richland, Washington.

Wilson, C. N. 1994. Evaluation of Melter-System Technologies for Vitrification of High-Sodium Content Low-Level Radioactive Liquid Wastes. WHC-SD-WM-RD-044, Rev. 0, Westinghouse Hanford Company, Richland, Washington. 